\title{
Measurements of atmospheric mercury in Shanghai during September 2009
}

\author{
H. R. Friedli ${ }^{1}$, A. F. Arellano Jr. ${ }^{1,}$, F. Geng ${ }^{2}$, C. $\mathrm{Cai}^{2}$, and L. Pan ${ }^{2}$ \\ ${ }^{1}$ Atmospheric Chemistry Division, National Center for Atmospheric Research, P.O. Box 3000, Boulder, CO 80307, USA \\ ${ }^{2}$ Shanghai Meteorological Bureau, Shanghai 200135, China \\ * now at: Department of Atmospheric Sciences, University of Arizona, P.O. Box 210081, Tucson, AZ 85721, USA
}

Received: 11 November 2010 - Published in Atmos. Chem. Phys. Discuss.: 13 December 2010

Revised: 17 March 2011 - Accepted: 7 April 2011 - Published: 27 April 2011

\begin{abstract}
We report on total gaseous mercury (TGM) measurements made in Pudong, Shanghai in August/September 2009. The average TGM was $2.7 \pm 1.7 \mathrm{ng} \mathrm{m}^{-3}$. This represents about $90 \%$ of the total atmospheric mercury. This is an underestimate for an annual-mean concentration because the meteorology in September favored predominantly easterly oceanic air, replaced in other seasons by airflow from industrial areas. The observed TGM follows a pattern seen in other cities around the world: a background elevated over mean hemispheric background $\left(1.5 \mathrm{ng} \mathrm{m}^{-3}\right)$, and pollution plumes of different magnitude and duration, interspersed with very sharp spikes of high concentration $\left(60 \mathrm{ng} \mathrm{m}^{-3}\right)$. The September 2009 Shanghai measurements are lower than those reported for most other Chinese cities and Mexico City, and similar to concentrations found in some Asian and in North American cities. Such comparisons are tenuous because of differences in season and year of the respective measurements. Our results should not be used for regulatory purposes. We find that the observed TGM are most likely coming from coal fired power plants, smelters and industrial sources, based on its high correlation with $\mathrm{NO}_{\mathrm{x}}, \mathrm{SO}_{2}, \mathrm{CO}$ and wind directions.
\end{abstract}

\section{Introduction}

China has become a fast economical growth country in recent years. The ongoing industrialization of China has caused rapid expansion of power demand and basic materials production, two processes which result in increased release of mercury to the atmosphere (Pirrone et al., 2010). This has significant regional and global consequences: direct emissions and evasion from previously deposited mercury affect

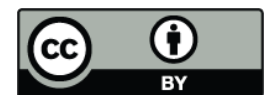

Correspondence to: H. R. Friedli (friedli@ucar.edu) the regional atmospheric concentration, and lofted pollution plumes exported eastwards by the warm conveyor belt impact Northern Hemispheric (NH) concentrations.

The ecological concern of mercury pollution is its toxicity. The most important toxic form of mercury, neurotoxic methyl mercury, is formed by the conversion of ionic mercury in water bodies and bio-accumulation through the food chain into fish (NRC, 2000). Other exposure to humans and animals is by consumption of grains and vegetation (Zhang et al., 2010) containing mercury accumulated from wet and dry deposition to plants and soil, or uptake from heavily contaminated soil. Inhalation of gaseous elemental mercury is hazardous in cases of gross exposure, e.g. in artisan gold production or mercury mining.

Atmospheric mercury exists in three operationally-defined species with distinctly different physical properties and distributions. Gaseous elemental mercury (GEM) in the Northern Hemisphere averages about $1.5 \mathrm{ng} \mathrm{m}^{-3}$ and accounts for about $95-97 \%$ of all tropospheric mercury. GEM has low chemical reactivity and water solubility, low deposition rate and accordingly exhibits a long atmospheric lifetime of 0.5 to $2 \mathrm{yr}$ depending on the environment. The other two major atmospheric species, gaseous ionic mercury (mostly called RGM or reactive gaseous mercury) and mercury contained in aerosol (particulate $\mathrm{Hg}$ or $p \mathrm{Hg}$ ) are more water soluble, more readily washed out and have shorter lifetimes of days to weeks and therefore are deposited closer to emission sources. The sum of the rural background concentration for these two species is in the range of $3-5 \%$ of the total mercury loading, but the contributions from point source can be much higher.

For China, including Shanghai, the major mercury sources to the atmosphere are coal combustion, i.e. coal fired power plants (CFPP), industrial boilers and domestic use, emissions from smelters (mostly $\mathrm{Zn}, \mathrm{Pb}, \mathrm{Cu}, \mathrm{Au}$ ) and incinerators, manufacturing (cement, iron and steel, batteries and lamps), and transportation releases from roads and harbors (Streets et al., 2005). The wind direction in Shanghai is

Published by Copernicus Publications on behalf of the European Geosciences Union. 
strongly seasonal resulting in exposure of mercury from different anthropogenic sources. During the harvesting season, the Shanghai area is affected by mercury from biomass burning emissions carried by southerly winds (Wang et al., 2002). As deposition from RGM and $p \mathrm{Hg}$ from point sources is high in China (Selin et al., 2007), soil evasion driven by insolation and wind becomes a significant contributor to mercury in the surface air layer.

Data on atmospheric mercury exist for many Chinese cities (see Table 3) but we are not aware of published gas phase mercury data for Shanghai. Here, we present atmospheric mercury measurements taken as part of an exploratory campaign called Megacity Impacts on Regional And Global Environments (MIRAGE-Shanghai 2009, http: //www.acd.ucar.edu/mirage). MIRAGE-Shanghai 2009 was conducted in collaboration with the Shanghai Meteorological Bureau (SMB). The goal of the campaign is to assess pollution and its precursors in preparation for detailed possible fieldwork in the future. The main objective of the mercury component of this campaign was to continuously measure atmospheric mercury during August/September 2009 in SMB, Pudong, Shanghai. Total gaseous mercury (TGM) measurements were taken using a Tekran 2537A instrument and correlated with simultaneous meteorological (wind direction and speed) and chemical $\left(\mathrm{CO}, \mathrm{SO}_{2}, \mathrm{NO}_{\mathrm{x}}\right)$ measurements, in order to elucidate meteorological patterns and potential mercury source types. The Shanghai TGM results are then contrasted with those from other regional and global observations to provide broader context of the measurements.

\section{Methods}

\subsection{Sampling site}

Continuous TGM samples were collected and analyzed on the top of the SMB building in August/September 2009. The sampling point is located at $31^{\circ} 13^{\prime} 48^{\prime \prime} \mathrm{N}$ and $121^{\circ} 32^{\prime} 24^{\prime \prime} \mathrm{E}$ at an altitude of 19 ma.s.l. (see Fig. 1). $\mathrm{SO}_{2}, \mathrm{NO}_{\mathrm{x}}, \mathrm{CO}$ and wind were measured at the same site as part of the ongoing data record for this station. The building is bordered by a large city park to the south, a green belt of conifers and deciduous trees along the streets, and major traffic arteries to the north and west. It is surrounded by high-rise buildings in the north, south, and west, while the east is devoid of large buildings. It is also in proximity to numerous mercury sources as indicated in Fig. 1, with the sources classified as coal combustion, smelters and industrial.

\subsection{Total gaseous mercury (TGM) measurements}

TGM was measured with a Tekran 2537A analyzer (SN 119) programmed for 300-s time resolution (Friedli et al., 2004). This instrument operates under the assumption that atmospheric GEM and RGM are quantitatively collected on gold cartridges, except for a fraction of RGM that may be lost

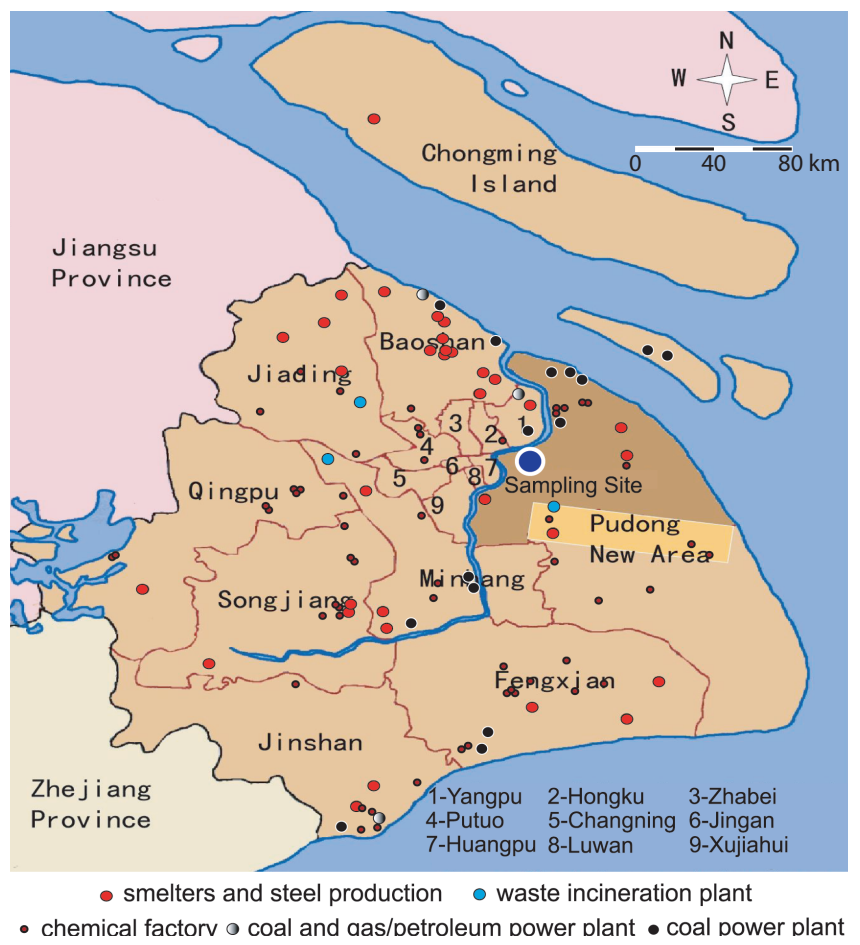

Fig. 1. Location of sampling site and major $\mathrm{Hg}$ sources within the surrounding area.

on internal surfaces, including on the inlet tubing. The instrument is factory-calibrated and in the field response factors were checked every $24 \mathrm{~h}$ using the internal mercury permeation cell. Zero air (freed of trace mercury by passing through a charcoal/iodine absorber) was used for instrument cleanup and operation, and as zero mercury blank. Argon (99.999\% purity) was utilized to flush the mercury desorbed from the heated cartridges into the cold vapor atomic fluorescence detector. Samples at $1.51 \mathrm{~min}^{-1}\left(760 \mathrm{~mm} \mathrm{Hg}, 0^{\circ} \mathrm{C}\right)$ were aspirated from outside the air-conditioned instrument building through $3.2 \mathrm{~m}$ of $1 / 4$ inch Teflon tubing. The intake was located $1.8 \mathrm{~m}$ outside from the east wall of the building. The sample line inside the building was kept heated sufficiently to avoid condensation on high humidity days. Particulates were removed from the sample stream with a $47 \mathrm{~mm}$ 0.5 micron Teflon filter placed at the intake of the Tekran instrument. These filters were replaced once per week during the experiment.

The instrument performed reliably. In particular, the gold cartridges remained well-balanced. The response factors varied by $12.3 \%$, displaying two minima and maxima coinciding to two pollution events (high $\mathrm{NO}_{\mathrm{x}}$ and $\mathrm{SO}_{2}$ ), which caused partial poisoning of the gold cartridges. A similar but more severe deactivation behavior had been previously observed during the ACE-Asia experiment (Friedli et al., 2004). For the Shanghai measurements, the sensitivity was fully regained in a matter of days in less polluted air. During 
the course of the experiment we also observed spikes of 5$30 \mathrm{~min}$ duration with up to $60 \mathrm{ng} \mathrm{m}^{-3}$ TGM. There was no operational explanation for their occurrence (see later discussion in Sect. 3.1).

RGM and particulate mercury are generally higher in polluted urban locations as compared to rural areas and therefore the impact of such compositions on the validity of measurements made with a Tekran instrument must be considered. Part of RGM may not be accounted for because of its stickiness to tubing and filters and its variability could introduce hysteresis effects. Speciated RGM measurements in Chinese (Shang et al., 2003) and other cities indicate that, except in cases of extreme point sources, RGM always remains in the $\mathrm{pg} \mathrm{m}^{-3}$ range as contrasted to GEM in $\mathrm{ng} \mathrm{m}^{-3}$ and thus accounts for a small fraction of the total gaseous mercury. In the case of $p \mathrm{Hg}$, the particulates are predominantly $>1.6 \mathrm{mi}-$ cron and therefore are kept out of the Tekran instrument by the filter. The contribution of $p \mathrm{Hg}$ to the mercury budget in Shanghai can be estimated from the extensive measurements by Xiu et al. (2009) of mercury in particles in the ambient air. The total particulate mass (TPM) in Shanghai seasonally varies by a factor of about 3 in the Xiu et al. (2009) data set and is large under polluted conditions but its mercury content varies only from 1.5 to $2.5 \mathrm{ppm}$. Compared to the TGM average of $2.7 \pm 1.7 \mathrm{ng} \mathrm{m}^{-3}$ (see results in Sect. 3) and an average of $0.27 \mathrm{ng} \mathrm{m}^{-3}$ of $p \mathrm{Hg}$ (Xiu et al., 2009), the average contribution of $p \mathrm{Hg}$ to the mercury mass balance is $9.1 \%$. Based on these arguments, we conclude that the TGM measurements account for at least $90 \%$ of the atmospheric mercury observed and can be considered as a reasonable representation for atmospheric mercury at the sampling site during September 2009.

\subsection{Complementary measurements: $\mathrm{NO}_{\mathrm{x}}, \mathrm{SO}_{2}, \mathrm{CO}$ and wind}

These measurements were taken by the SMB staff using instrumentations described in Geng et al. (2009). NO-NO ${ }_{2}^{-}$ $\mathrm{NO}_{\mathrm{x}}$ was measured with a chemiluminescence trace level analyzer (TEL; Model 42iTL) programmed for 60-s time resolution. The Model 42iTL operates on the principle that nitric oxide (NO) and ozone $\left(\mathrm{O}_{3}\right)$ react to produce a characteristic luminescence that is linearly proportional to the NO concentration. It operates in two flow modes, $\mathrm{NO}$ and $\mathrm{NO}_{\mathrm{x}}$, where in the $\mathrm{NO}_{\mathrm{x}}$ mode the $\mathrm{NO}_{2}$ is first converted to NO. The instrument has a detection limit (DL) of 0.4 ppbv. CO was observed using an EC9830B/ECOTECH carbon monoxide analyzer programmed for $60-\mathrm{s}$ time resolution. The analyzer generates infrared radiation (IR) that is absorbed by the $\mathrm{CO}$ within the 5-m folded path length. The gas filter correlation wheel facilitates rejection of interferences and the narrow band-pass filter ensures measuring only the $\mathrm{CO}$-sensitive IR wavelengths. The analyzer had DL value of $0.05 \mathrm{ppmv} . \mathrm{SO}_{2}$ was measured with a ML9850/ECOTECH analyzer, which is an ultraviolet (UV) fluorescence spectrometer designed to
Table 1. Summary Statistics of the Time Series.

\begin{tabular}{lcccc}
\hline & All Data & Background $^{1}$ & Minor $^{2}$ & Major $^{3}$ \\
\hline TGM $\left(\mathrm{ng} \mathrm{m}^{-3}\right)$ & $2.7 \pm 1.7$ & $2.4 \pm 1.2$ & $2.5 \pm 0.5$ & $3.8 \pm 1.6$ \\
$\mathrm{CO}($ ppbv) & $446 \pm 215$ & $397 \pm 170$ & $470 \pm 140$ & $622 \pm 380$ \\
$\mathrm{NO}_{\mathrm{x}}$ (ppbv) & $18.7 \pm 13.0$ & $16.8 \pm 5.0$ & $21.7 \pm 13.3$ & $28.4 \pm 19.1$ \\
$\mathrm{SO}_{2}$ (ppbv) & $3.7 \pm 5.2$ & $1.5 \pm 1.1$ & $6.6 \pm 4.8$ & $10.2 \pm 8.6$ \\
Wind Dir. $^{4}(\mathrm{deg})$ & $77 \pm 39$ & $77 \pm 26$ & $75 \pm 92$ & $116 \pm 135$ \\
Wind Spd. $\left(\mathrm{m} \mathrm{s}^{-1}\right)$ & $1.5 \pm 0.9$ & $1.6 \pm 1.0$ & $1.5 \pm 0.7$ & $1.3 \pm 0.8$ \\
\hline
\end{tabular}

131 August-8 September 2009, ${ }^{2} 7$ September-11 September 2009,

${ }^{3} 11$ September-13 September $2009,{ }^{4}$ calculated as median \pm inter quartile range.

continuously measure low concentration of $\mathrm{SO}_{2}$ in ambient air, programmed for 60-s time resolution. The ML9850 analyzer comprises an optical sensor assembly, an electronic signal preprocessor module, microprocessor-based control and computation electronics, and a pneumatic system that samples ambient air. The analyzer had DL value of $0.5 \mathrm{ppbv}$. The data for wind speed and direction were obtained from a MILOS500 automatic weather station.

\section{Results and discussion}

This section begins with a description of time series for $\mathrm{TGM}, \mathrm{CO}, \mathrm{SO}_{2}, \mathrm{NO}_{\mathrm{x}}$, and wind parameters (Sect. 3.1). This is followed by an assessment of the diurnal cycle and detailed evaluation of three distinct segments of the time series: (1) background, which is mostly at the beginning and end of the experiment under easterly flow conditions (Sect. 3.2), (2) a minor Hg plume event observed around 8 September (Sect. 3.2), and (3) a major Hg plume event observed around 12 September (Sect. 3.2). Another Hg plume observed during the early part of the experiment (1 September) is not included in the analysis due to lack of complete $\mathrm{SO}_{2}$ and $\mathrm{NO}_{\mathrm{x}}$ data during this period.

\subsection{Time series for TGM, $\mathrm{CO}, \mathrm{SO}_{2}, \mathrm{NO}_{\mathrm{x}}$ and wind}

\subsubsection{Overall description}

The time series for the period of 30 August to 22 September 2009 are plotted in Fig. 2. All data points are averaged to the 300-s time resolution of the TGM measurements. The statistics of the time series are summarized in Table 1. Overall, TGM at Pudong, Shanghai during the experiment is characterized by: (1) a relatively well-defined background and diurnal cycle, and (2) intermittent high concentrations that are mostly related to changes in air parcels containing high levels of pollution.

The mean concentration for TGM is $2.7 \pm 1.7 \mathrm{ng} \mathrm{m}^{-3}$, which is higher than the mean value for the Northern Hemisphere of $1.5 \mathrm{ng} \mathrm{m}^{-3}$. The large standard deviation is indicative of the large variability in the TGM measurement. As 


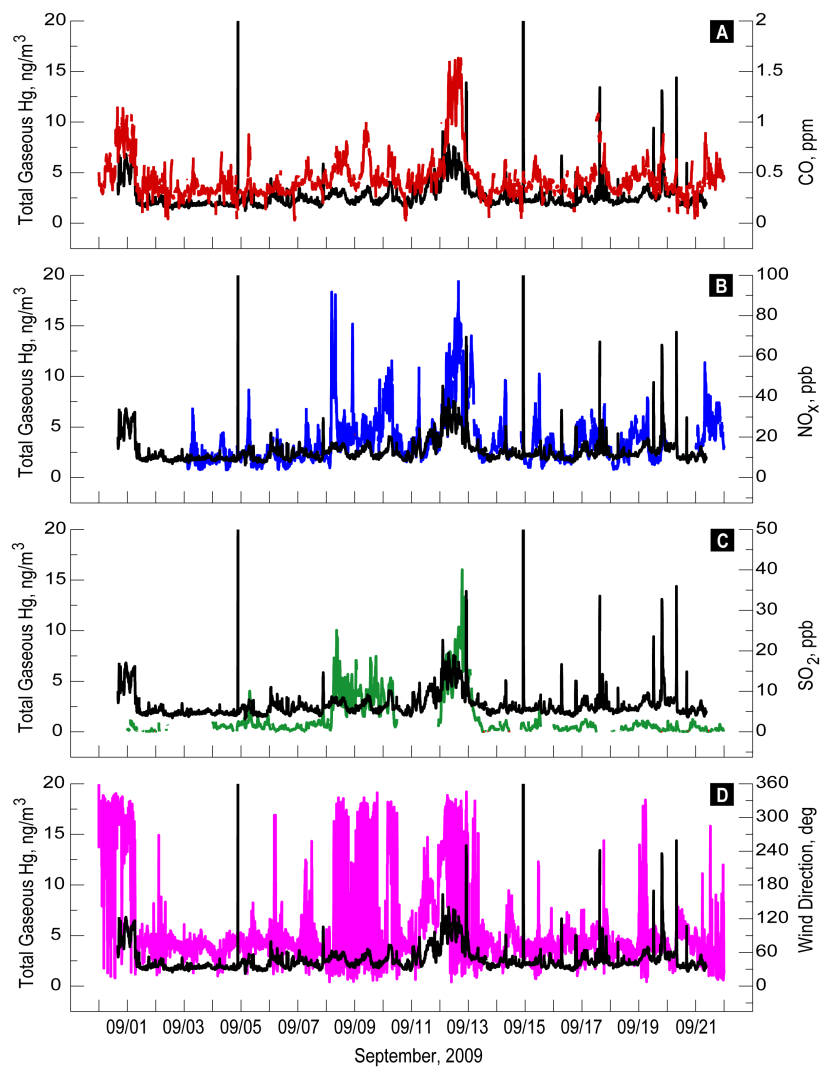

Fig. 2. Time series of TGM (black), $\mathrm{CO}$ (red), $\mathrm{NO}_{\mathrm{x}}$ (blue), $\mathrm{SO}_{2}$ (green), and wind direction (magenta) for the entire experiment period.

seen in Fig. 2 (and in succeeding sections of this paper), the variability of TGM is strongly correlated with the wind direction. For this period, the dominant meteorology is an easterly airflow from China Sea and North Pacific Ocean. This represents a relatively clean and processed air largely contributing to the TGM background observed in the Pudong site. The change in the wind patterns (and other meteorological conditions) during the course of the entire experiment correlates well with the three clearly defined plume events and the more complex period during the last third of the experiment.

However, we should note that the meteorological patterns during the experiment only represent a small fraction of the annual-mean meteorological condition in this area. In particular, we find that the wind pattern changes quite significantly across the four seasons of the year, with large fractions of wind directed from the northwest, southeast and northeast. These fractions are shown as wind roses in Fig. 3a. In comparison, the wind pattern during September is mostly northeasterly (Fig. 3b) resulting in relatively low concentrations of TGM for this period. The TGM levels reflect the seasonality in $\mathrm{CO}$ and $\mathrm{NO}_{\mathrm{x}}$ levels observed in Shanghai by Ran et al. (2009), which reports maximum levels of $\mathrm{CO}$ and $\mathrm{NO}_{\mathrm{x}}$ in winter and minima in summer.
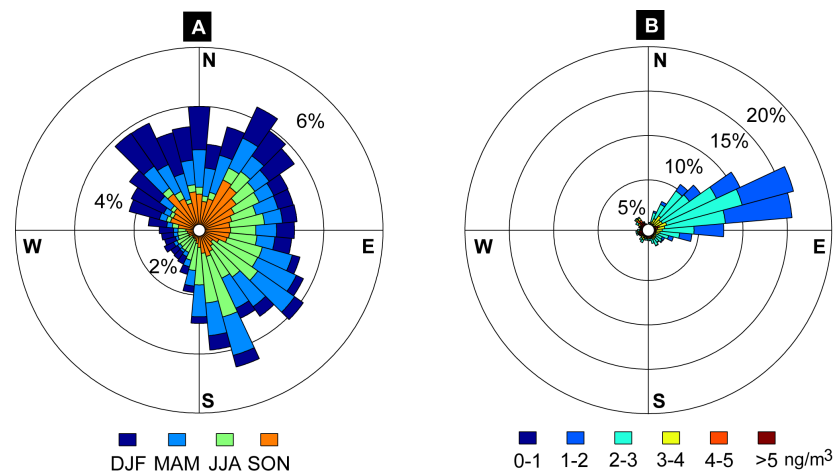

Fig. 3. Measurements of wind direction taken at Pudong WMO meteorological station for the entire year of 2009 (A). The station is located at $31.133^{\circ}$ and $121.783^{\circ}$ longitude in close proximity to the sampling site of this study. The wind data are plotted as wind roses. The length of each slice corresponds to the frequency of wind (in \%) observed at the site during 2009 where the winds are blowing from a particular direction. The shaded portion of the wind rose in panel A corresponds to the relative frequency of wind data associated with a particular wind direction observed during the different seasons of the year. The seasons are defined here as winter (DJF), spring (MAM), summer (JJA) and fall (SON). In comparison, a wind rose for the August/September time period is plotted in (B), showing the relative frequency of the data on TGM concentrations associated with a particular wind direction.

Over the course of the experiment, we observed seven TGM spikes $>10 \mathrm{ng} \mathrm{m}^{-3}$ of short duration $(5-30 \mathrm{~min})$ and values of up to $60 \mathrm{ng} \mathrm{m}^{-3}$. These spikes did not correspond with unique wind directions. Such events are common as they were also observed in many other cities (e.g. in Guiyang by Feng et al., 2004, in Toronto, Canada by Song et al., 2009, and in Houston, TX, by Brooks et al., 2009). One interpretation would be short-term and intermittent high concentration pockets of $\mathrm{Hg}$ released near the measuring site that are not associated to combustion-related activities.

\subsubsection{Diurnal variation}

We present in Fig. 4 the diurnal cycle of TGM and CO as derived from the entire time series. The diurnal cycle is calculated as the median value for each hour of the time series. A polynomial fit to the derived data is shown to provide an overall trend. We find that the observed TGM follows a clear diurnal cycle which is mainly a reflection of the background characteristic of TGM in the area. This is consistent with many other urban cases, which report similar strong diurnal variations in atmospheric $\mathrm{Hg}$ (e.g. Song et al., 2009). The observed $\mathrm{CO}$ also shows a diurnal cycle that is very consistent with the changes during the day of the boundary layer and emission patterns, most notably during rush hours (e.g. Tie et al., 2007; Stephens et al., 2008; Ran et al., 2009). The $\mathrm{CO}$ diurnal cycle shows a major peak during the morning rush hours followed by a drop in concentration in the middle 


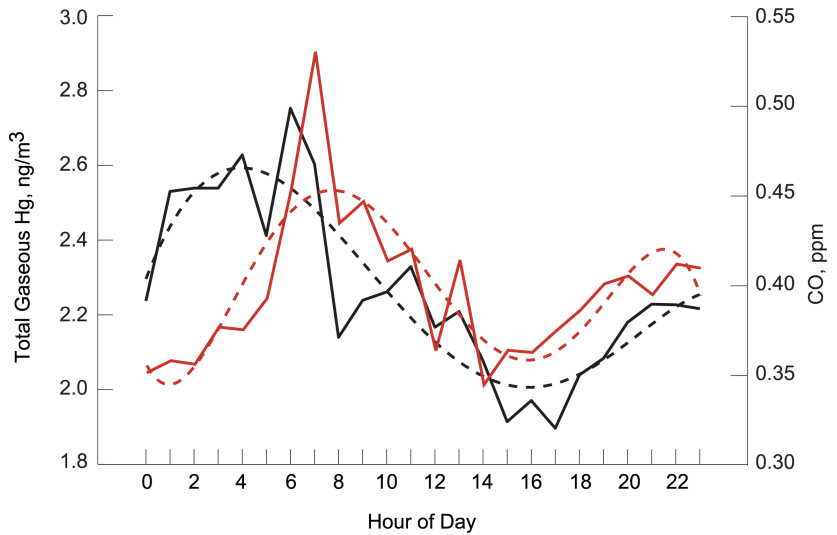

Fig. 4. Diurnal cycle of TGM (black) and CO (red) based on data for the entire experiment period. Dashed lines correspond to a polynomial fit of the data.

of the day due to the growth in the boundary layer height. A minor peak is observed in the evening as a result of the evening rush hours followed by a drop of the boundary layer height during the night. This diurnal pattern in $\mathrm{CO}$ concentrations is out-of-phase with the $\mathrm{Hg}$ diurnal pattern, which appears to coincide only to changes in the boundary layerheight (Geng et al., 2007). We have not looked at the diurnal cycles of observed $\mathrm{NO}_{\mathrm{x}}$ and $\mathrm{SO}_{2}$ because of incomplete data for the whole experiment. However, Ran et al. (2009) have reported seasonal diurnals for $\mathrm{NO}_{\mathrm{x}}$ in Shanghai consistent with the $\mathrm{CO}$ diurnals of this work.

\subsection{Background during the experiment}

The background is characterized by flow of aged easterly air low in $\mathrm{NO}_{\mathrm{x}}$ and $\mathrm{SO}_{2}$ that has resided several days in the boundary layer over the ocean and contains a mean of $2.4 \pm 1.2 \mathrm{ng} \mathrm{m}^{-3}$ TGM (see Table 1 and Fig. 5a). Back trajectories (not shown) trace the air parcels to Japan crossing over Korea 3 to 5 days earlier. This TGM value exceeds the Northern Hemisphere mean value of $1.5 \mathrm{ng} \mathrm{m}^{-3}$ because at the measuring site the mercury background consists of the mercury contained in the advected air (Korea and Japan), augmented by soil evasion from large previously deposited mercury (Selin et al., 2007), and contributions from small local sources.

\subsection{Minor and major pollution plumes}

The major plume event (see Table 1) exhibits the highest mean concentration of TGM, $\mathrm{CO}, \mathrm{SO}_{2}$, and $\mathrm{NO}_{\mathrm{x}}$. As shown in Fig. 2, correlations exist between TGM, wind direction, and the other pollutants, especially during the minor and major plume events. Here, we calculate the overall correlation factors with those in the minor and major plume. These factors are calculated based on a subset of the data where simul-

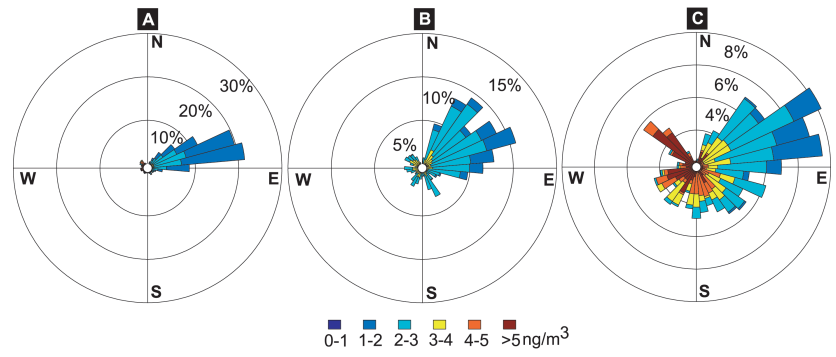

Fig. 5. TGM data plotted as wind roses over the following time periods of the study: background (A), minor (B), and major plume (C). These periods are defined in Sect. 3 and Table 1. The length of each slice corresponds to the frequency of wind data (in \%) blowing at a particular direction over the time period. Note that the unaccounted percentages are associated with missing data.The shaded portion of each slice corresponds to the relative frequency of a particular range of TGM concentration values associated with a particular wind direction.

Table 2. Correlation coefficients between the different measurements.

\begin{tabular}{lcccccc}
\hline & $\begin{array}{c}\mathrm{TGM} \\
\mathrm{CO}\end{array}$ & $\begin{array}{c}\mathrm{TGM} \\
\mathrm{NO}_{\mathrm{x}}\end{array}$ & $\begin{array}{c}\mathrm{TGM} \\
\mathrm{SO}_{2}\end{array}$ & $\begin{array}{c}\mathrm{TGM} \\
\text { Wind Dir. }\end{array}$ & $\begin{array}{c}\mathrm{NO}_{\mathrm{x}} \\
\mathrm{SO}_{2}\end{array}$ & $\begin{array}{c}\mathrm{NO}_{\mathrm{x}} \\
\mathrm{CO}\end{array}$ \\
\hline All Data & 0.4 & 0.3 & 0.3 & 0.2 & 0.7 & 0.8 \\
Minor & 0.6 & 0.4 & 0.3 & 0.4 & 0.4 & 0.2 \\
Major & 0.8 & 0.7 & 0.7 & 0.6 & 0.8 & 0.9 \\
\hline
\end{tabular}

taneous measurements are available for all of the variables observed.

As shown in Table 2, the two plumes do not only show the highest concentrations (see Table 1) but also the highest correlation with TGM, decreasing from $\mathrm{CO}$ to $\mathrm{NO}_{\mathrm{x}}$ and $\mathrm{SO}_{2}$. While the correlation between TGM and CO is statistically higher than that with $\mathrm{SO}_{2}$ and $\mathrm{NO}_{\mathrm{x}}$, the variability of TGM cannot be explained by the variability of $\mathrm{CO}$ alone. There are cases in the time series wherein changes in TGM are not directly associated with the changes in $\mathrm{CO}$, suggesting other sources in the variability of TGM.

A desirable outcome from these measurements would be the ability to identify source receptor relationships as it has been accomplished for simpler cases with well-constrained sources (Rutter et al., 2009; Manolopoulos et al., 2007). For Shanghai in September, Streets et al. (2005) have estimated that $71.4 \%$ of $\mathrm{Hg}$ comes from coal combustion, $12.5 \%$ from smelters and $16.1 \%$ from others sources. As noted above, we find that observed TGM of the major plume are very wellcorrelated with wind directions and combustion-related pollutants pointing along the pathways where $\mathrm{Hg}$ emitting industries are located. In particular, Fig. $5 \mathrm{c}$ in conjunction with Fig. 1, indicates that the high concentration of $\mathrm{Hg}$ in the major plume is directly related to the northwesterly and southwesterly airflow pointing to nearby smelters and CFPPs in 
Shanghai as its sources. For example, TGM concentrations during the morning hours of 12 September 2009 peak at about $7 \mathrm{ng} \mathrm{m}^{-3}$. They are associated with air parcels blowing from northern Baoshan, where a cluster of smelters and power plants are located. Back trajectories trace the air parcels to Baoshan one to two hours earlier.

$\mathrm{SO}_{2}, \mathrm{NO}_{\mathrm{x}}$, and $\mathrm{CO}$ are the most relevant tracers for TGM. While $\mathrm{SO}_{2}$ and $\mathrm{NO}_{\mathrm{x}}$ are co-emitted with $\mathrm{Hg}$ from CFPPs and nonferrous smelting processes, their relative abundance vary greatly among industries, fuel types, degree of pollution abatement and within each source categories (Lin et al., 2010; Lu et al., 2010). This difference in abundance provides a way to identify the dominance of coal combustion or smelting in the TGM plume that we observed in this study. High temperature combustion of coal in CFPP, in conjunction with increasing control technologies, results in relatively low $\mathrm{SO}_{2}$ and high $\mathrm{NO}_{\mathrm{x}}$ emissions. On the other hand, the high sulfur content in the ore during smelting results to relatively high $\mathrm{SO}_{2}$ emissions from large-scale smelters. For Shanghai in 2006, Zhang et al. (2009) reported anthropogenic $\mathrm{NO}_{\mathrm{x}}$ and $\mathrm{SO}_{2}$ emissions in the year 2006 of 631 and $618 \mathrm{Gg} \mathrm{yr}^{-1}$, respectively (ratio of 1.02). This is a shift from $\mathrm{SO}_{2}$ to $\mathrm{NO}_{\mathrm{x}}$ dominant source in Shanghai reported by an early study by Streets and Waldhoff (2000) for the year 1995. Our data show that the $\mathrm{NO}_{\mathrm{x}}$ mass loading during the background period of this study is a factor of 11.6 higher than the $\mathrm{SO}_{2}$ mass loading. This factor is calculated using a Monte Carlo approach to account for the large variability in the mass loading (Table 1). In particular, a large sample of $\mathrm{NO}_{\mathrm{x}}$ and $\mathrm{SO}_{2}$ mass loading was drawn from a multivariate lognormal distribution using mean and standard deviation shown in Table 1 and correlation factors shown in Table 2 . The high $\mathrm{NO}_{\mathrm{x}}$ suggests the dominance of combustion from the transportation sector as a local source (background) of $\mathrm{NO}_{\mathrm{x}}$ observed at the Pudong site. On the other hand, the ratio between the enhancement (relative to the background) in $\mathrm{NO}_{\mathrm{x}}$ and $\mathrm{SO}_{2}$ mass loading within the major plume is $1.4 \pm 0.1$ based on a similar Monte Carlo simulation. This ratio suggests a relatively $\mathrm{NO}_{\mathrm{x}}$-rich pollution (on top of the local source from transportation) during the major plume event. This pollution is further characterized by a significantly high correlation between TGM and $\mathrm{NO}_{\mathrm{x}}(R=0.8)$ relative to the background $(R=0.3)$. Because transportation is a minor contributor to TGM during the major plume event, our data indicates that $\mathrm{NO}_{\mathrm{x}}$-dominant sources like CFPPs contribute largely to the observed enhancements in TGM relative to $\mathrm{SO}_{2}$-dominant pollution from smelters. The larger contribution of CFPP to observed TGM is supported by Streets et al. (2005) for Shanghai in September.

Although TGM have the highest correlation factor with $\mathrm{CO}$, particularly during the minor/major plumes, the sources of $\mathrm{CO}$ are difficult to assign to a specific industry and source type because Shanghai has diverse industries with elevated emission factors for CO. Biomass burning (BMB) with well defined TGM/CO emission ratios, is not a contributor of atmospheric mercury in September in Shanghai. The two biggest $\mathrm{CO}$ sources in Shanghai associated with mercury emissions are industrial plants (cement, bricks, boilers, iron and steel) and transportation. CFPPs, although large mercury emitters, are minor sources for CO. Domestic coal combustion is a large $\mathrm{CO}$ emissions for China as a whole but it is small in Shanghai (Streets et al., 2006). A CO contribution from transportation is suggested in the CO diurnal (Fig. 4) with maxima coinciding with traffic peak hours (see also Ran et al., 2009).

It is interesting to note that for some segments of the experiment TGM concentrations are elevated in the absence of elevated $\mathrm{SO}_{2}$ and/or $\mathrm{NO}_{\mathrm{x}}$, suggesting that there are unique sources, not yet elucidated, that emit mostly TGM and CO (e.g. 20 September).

\subsection{Comparative data}

Fang et al. (2009) have reviewed the distribution of atmospheric mercury (non-speciated) in the Pacific region: Korea, Japan, China and Taiwan. Their data cover various seasons and time periods and therefore are not directly comparable with our short duration measurements at a single site. This is of concern because the wind pattern in September 2010 are untypical for annual winds but bring mostly aged relatively clean air from the east, the ocean. Other months (Fig. 3) show a progressive change in dominant wind direction to northerly and westerly flow with the highest mercury contributions and southerly flows from areas with BMB during midsummer. In Table 3 we compare atmospheric mercury observed in cities in China, in other Asian cities and in the Americas. Additional measurements for China can be found in Feng (2010) and Sprovieri et al. (2010). In this compilation, Shanghai in September 2009 shows the lowest TGM pollution among Chinese cities listed. Tokyo and Seoul are in the same range as Shanghai, as are US cities and Toronto. Mexico City is more polluted, similar to Chinese cities.

\section{Conclusions}

This work is a time and spatially limited snapshot of atmospheric mercury in a relatively clean megacity. During September 2009 at the SMB, Pudong, Shanghai, the mean atmospheric mercury was $2.7 \pm 1.7 \mathrm{ng} \mathrm{m}^{-3}$. The reason for the relative low value is the fact that most of the sampling period was under the influence of clean easterly airflow. However, this is an exceptional condition for Shanghai as in other seasons the winds are from directions along the path where anthropogenic point sources are located. The mean TGM, which represents roughly $90 \%$ of total atmospheric mercury (the remainder being RGM, but mostly $p \mathrm{Hg}$ ), is therefore an underestimate for an annual-mean Shanghai TGM value.

The observed TGM in Shanghai follows a pattern seen in other cities around the world: a background elevated relative 
Table 3. Atmospheric $\mathrm{Hg}$ in Chinese and other cities.

\begin{tabular}{lccl}
\hline & $\begin{array}{c}\text { TGM } \\
\left(\mathrm{ng} \mathrm{m}^{-3}\right)\end{array}$ & Date & Reference \\
\hline Beijing & $8.3 \pm 3.6$ & $01 / 2005$ & Wang et al. (2006, 2007) \\
& $6.5 \pm 5.2$ & $04 / 2005$ & \\
& $4.9 \pm 3.3$ & $07 / 2005$ & \\
Guangzhou & $6.7 \pm 3.5$ & $10 / 2005$ & \\
Changchun & $13.5 \pm 7.1$ & $01 / 2005$ & Wang et al. (2007) \\
& 18.4 & $07 / 2009$ & Fang et al. (2004) \\
Guiyang & $(4.7-79.6)$ & & \\
& $8.4 \pm 4.9$ & $11 / 2001-$ & Feng et al. (2004) \\
Chongqing & $6.74 \pm 0.37$ & $08 / 2006$ & Yang et al. (2009) \\
Shanghai & $2.7 \pm 0.7$ & $09 / 2009$ & This work \\
Seoul & $14.4 \pm 9.6$ & $1987-1988$ & Kim et al. (2005, 2009) \\
& $5.34 \pm 3.92$ & $1999-2000$ & \\
Tokyo & $2.7 \pm 3.6$ & $2000-2001$ & Sakata and Moromato (2002) \\
Chicago & $3.6 \pm 2.9$ & $1994-1995$ & Landis et al. (2002) \\
Detroit & $1.2-4.0$ & $1995-2002$ & Lynam and Keeler (2002) \\
E. St. Louis & $4.6 \pm 6.0$ & $10 / 2002$ & Monolopulous et al. (2007) \\
Toronto & 4.5 & $2002-2004$ & Song et al. (2009) \\
Mexico City & $7.2 \pm 4.8$ & $03 / 2006$ & Rutter et al. (2009) \\
\hline & & &
\end{tabular}

to rural and mean hemispheric background, and pollution plumes of different magnitude and duration, interspersed with very sharp spikes of high concentration but short duration. The mercury pollution at the site, depending on wind direction, is composed of mercury advected with easterly air arriving from the China Sea and Pacific Ocean, mercury anthropogenic emissions mostly from northerly and westerly industrial centers, and mercury evasion from soil.

The $\mathrm{SO}_{2}, \mathrm{NO}_{\mathrm{x}}$ and wind measurements are correlated with TGM to variable degrees. The correlations are especially high during the major plume event consistent with the dominance of coal burning and smelter emission. We find that the major mercury contributors are CFPP, followed by smelters and poorly defined industrial sources well correlated with CO.TGM and CO have the highest correlation factors among measured pollutants, overall and particularly in the plumes, but there are no clear ties to known $\mathrm{CO}$ emitters, although industrial processing operations are suspected.

Looking into the future, we note that pollution from newer CFPPs is reduced depending on the level of use and type of modern abatement technologies. Importantly, this is also consequential for mercury speciation, which drives local deposition. Mercury at stack level can be essentially free of $p \mathrm{Hg}$ and low on RGM while in the raw combustion gases mercury is mostly in ionic and in particulate form (Wang et al., 2010). The large number of source types and the variation within source types and the variable degree of abatement makes detailed source-receptor analysis impossible or not worth while at this time because of unacceptable uncertainties.

To obtain a better assessment of variability and trends, mercury measurements (TGM, preferably augmented by speciated mercury and $\mathrm{Hg}$ analysis in aerosol) should be contin- ued or initiated at multiple locations in and around Shanghai. Integrated and long-term measurements $\left(\mathrm{NO}_{\mathrm{x}}, \mathrm{SO}_{2}, \mathrm{CO}\right.$ and meteorology) are mandatory given the large spatio-temporal variability in the observed concentrations. Such data are useful for tracking progress in pollution abatement and as input to predictive models of atmospheric $\mathrm{Hg}$.

Acknowledgements. We thank the SMB staff and MIRAGEShanghai team for helpful collaboration. Geng (email: fuhaigeng@263.net) is the main contact person for non-Hg data used in this study. We thank Electric Power Research Institute (EPRI) for the loan of the Tekran instrument. We also acknowledge the National Climatic Data Center for Pudong weather data used in Fig. 3a and NOAA Air Resources Laboratory for the HYSPLIT trajectories used as supporting information. We thank David Streets, Frank Flocke, Andy Weinheimer, and Xuexie Tie for helpful comments. The National Center for Atmospheric Research is sponsored by the National Science Foundation.

Edited by: X. Tie

\section{References}

Brooks, S., Luke, W., Cohen, M., Kelly, P., Lefer, B., and Rappenglueck, B.: Mercury species measured atop the Moody Tower TRAMP site, Houston, Texas, Atmos. Environ., 43(1), 1-11, 2009.

Denis, M. S., Song, X. J., Lu, J. Y., and Feng, X. B.: Atmosphericgaseous elemental mercury in downtown Toronto, Atmos. Environ., 40, 4016-4024, 2006.

Fang, F. M., Wang, Q. C., and Li, J. F.: Urban environmental mercury in Changchun, a metropolitan city in northeastern China: Source, cycle, and fate, Sci. Total Environ., 330, 159 170, doi:10.1016/j.scitotenv.2004.04.006, 2004.

Fang, G.-C., Wu,Y.-S., and Chang, T.-H.: Comparison of atmospheric mercury $(\mathrm{Hg})$ among Korea, Japan, China and Taiwan during 2000-2008, J. Hazard. Mater., 162, 607-615, 2009.

Feng, X.: Interactive comment on "Worldwide atmospheric mercury measurements: a review and synthesis of spatial and temporal trends" by F. Sprovieri et al., Atmos. Chem. Phys. Discuss., 10, C81-C82, 2010.

Feng, X. B., Shang, L. H., Wang, S. F., Tang, S. L., and Zheng, W.: Temporal variation of total gaseous mercury in the air of Guiyang, China, J. Geophys. Res., 109, D03303, doi:10.1029/2003JD004159, 2004.

Friedli, H. R., Radke, L. F., Prescott, R., Pan, L., Woo, J. H., and Carmichael, G. R.: Mercury in the atmosphere around Japan, Korea and China as observed during the 2001 ACE-Asia field campaign: measurements, distribution, sources, and implications, J Geophys. Res., 109, D19S25, doi:1029/2003JD004244, 2004.

Geng, F., Zhao, C., Tang, X., Lu, G., and Tie, X.: Analysis of ozone and VOCs measured in Shanghai: A case study, Atmos. Environ., 41, 989-1001, 2007.

Geng, F., Zhang, Q., Tie, X., Huang, M., Ma, X., Deng, Z., Yu, Q., Quan, J., and Zhao, C.: Aircraft measurements of $\mathrm{O}_{3}, \mathrm{NO}_{\mathrm{x}}$, $\mathrm{CO}, \mathrm{VOCs}$, and $\mathrm{SO}_{2}$ in the Yangtze River Delta region, Atmos. Environ., 43, 584-593, 2009.

Kim, K. H., Ebinghaus, R., Schroeder, W. H., Blanchard, P., Kock, H. H., Steffen, A., Froude, F. A., Kim, M. Y., Hong, S. M., and 
Kim, J. H.: Atmospheric mercury concentrations from several observatory sites in the northern hemisphere, J. Atmos. Chem., 50, 1-24, 2005.

Kim, S. H., Han, Y. J., Holsen, T. M., and Yi, S. M.: Characteristics of atmospheric speciated mercury concentrations (TGM, $\mathrm{Hg}(\mathrm{II})$ and $\mathrm{Hg}(\mathrm{p}))$ in Seoul, Korea, Atmos. Environ., 43, 32673274, doi:10.1016/j.atmosenv.2009.02.038, 2009.

Landis, M. S., Vette, A. F., and Keeler, G. J.: Atmospheric mercuryin the Lake Michigan basin: Influence of the Chicago/Gary urban area, Environ. Sci. Technol., 36, 4508-4517, 2002.

Lin, J.-T., McElroy, M. B., and Boersma, K. F.: Constraint of anthropogenic $\mathrm{NO}_{\mathrm{x}}$ emissions in China from different sectors: a new methodology using multiple satellite retrievals, Atmos. Chem. Phys., 10, 63-78, doi:10.5194/acp-10-63-2010, 2010.

Lu, Z., Streets, D. G., Zhang, Q., Wang, S., Carmichael, G. R., Cheng, Y. F., Wei, C., Chin, M., Diehl, T., and Tan, Q.: Sulfur dioxide emissions in China and sulfur trends in East Asia since 2000, Atmos. Chem. Phys., 10, 6311-6331, doi:10.5194/acp-106311-2010, 2010.

Lynam, M. M. and Keeler, G. J.: Comparison of methods for particulate phase mercury analysis: sampling and analysis, Anal. Bioanal. Chem., 374, 1009-1014, 2002.

Monolopoulos, H., Snyder, D., Schauer, J., Hill, J., Turner, J., Olson, M., and Krabbenhoft, D.: Sources of speciated atmospheric mercury at a residential neighborhood impacted by industrial sources, Environ. Sci. Techno., 41(16), 5626-5633, 2007.

National Research Council: Toxicological Effects of Methylmercury, Washington, DC, National Academy Press, 2000.

Pirrone, N., Cinnirella, S., Feng, X., Finkelman, R. B., Friedli, H. R., Leaner, J., Mason, R., Mukherjee, A. B., Stracher, G. B., Streets, D. G., and Telmer, K.: Global mercury emissions to the atmosphere from anthropogenic and natural sources, Atmos. Chem. Phys., 10, 5951-5964, doi:10.5194/acp-10-59512010, 2010.

Ran, L, Zhao, C., Geng, F., Tie, X., Tang, X., Peng, L., Zhou, G., Yu, Q., Xu, J., and Guenther, A.: Ozone photochemical production in urban Shanghai, China: Analysis based on ground level observations, J. Geophys. Res., 114, D15301, doi:10.1029/2008JD010752, 2009.

Rutter, A. P., Snyder, D. C., Stone, E. A., Schauer, J. J., GonzalezAbraham, R., Molina, L. T., Márquez, C., Cárdenas, B., and de Foy, B.: In situ measurements of speciated atmospheric mercury and the identification of source regions in the Mexico City Metropolitan Area, Atmos. Chem. Phys., 9, 207-220, doi:10.5194/acp-9-207-2009, 2009.

Sakata, M. and Marumoto, K.: Formation of atmospheric particulate mercury in the Tokyo metropolitan area, Atmos. Environ., 36, 239-246, 2002.

Selin, N. E., Jacob, D. J., Park, R. J., Yantosca, R. M., Strode, S., Jaegle, L., and Jaffe, D.: Chemical cycling and deposition of atmospheric mercury: Global constraints from observations, J. Geophys. Res., 112, DO2308, doi:10.1029/2006JD007450, 2007.

Shang, L., Feng, X., Zheng W., and Yan, H.: preliminary study of the distribution of speciated mercury species in the air of Guiyang city, China, J. Physique IV, 107(II), 1219-1222, 2003.

Song, X., Cheng, I., and Lu, J.: Annual atmospheric mercury species in Downtown Toronto, Canada, J. Environ. Monit., 11, 660-669, 2009.
Sprovieri, F., Pirrone, N., Ebinghaus, R., Kock, H., and Dommergue, A.: A review of worldwide atmospheric mercury measurements, Atmos. Chem. Phys., 10, 8245-8265, doi:10.5194/acp10-8245-2010, 2010.

Stephens, S., Madronich, S., Wu, F., Olson, J. B., Ramos, R., Retama, A., and Muñoz, R.: Weekly patterns of México City's surface concentrations of $\mathrm{CO}, \mathrm{NO}_{\mathrm{x}}, \mathrm{PM}_{10}$ and $\mathrm{O}_{3}$ during 19862007, Atmos. Chem. Phys., 8, 5313-5325, doi:10.5194/acp-85313-2008, 2008.

Streets, D. G. and Waldhoff, S. T.: Present and future emissions of air pollutants in China: $\mathrm{SO}_{2}, \mathrm{NO}_{\mathrm{x}}$, and $\mathrm{CO}$, Atmos. Environ., 34, 363-374, 2000.

Streets, D. G., Hao, J., Wu, Y., Jiang, J., Chan, M., Tian, H., and Feng, X.: Anthropogenic mercury emissions in China, Atmos. Environ., 39, 7789-7806, 2005.

Streets, D. G, Zhang, Q., Wang, L., He, K., Hao, J., Wu, Y., Tang, Y., and Carmichael, G.: Revisiting China's CO emissions after the TRACE-P mission: Synthesis of inventories, atmospheric modeling, and observations, J. Geophys. Res., 111, D14306, doi:10.1029/2006JD007118, 2006.

Tie, X., Madronich, S., Li, G. H., Ying, Z. M., Zhang, R., Garcia, A., Lee-Taylor, J., and Liu, Y.: Characterizations of chemical oxidants in Mexico City: A regional chemical/dynamical model (WRF-Chem) study, Atmos. Environ., 41, 1989-2008, 2007.

Wang, S. X., Zhang, L., Li, G. H., Wu, Y., Hao, J. M., Pirrone, N., Sprovieri, F., and Ancora, M. P.: Mercury emission and speciation of coal-fired power plants in China, Atmos. Chem. Phys., 10, 1183-1192, doi:10.5194/acp-10-1183-2010, 2010.

Wang, T., Wong, C. H., Cheung, T. F., Blake, D. R., Arimoto, R., Baumann, K., Tang, J., Ding, G. A., Yu, X. M., Li, S. Y., Streets, D. G., and Simpson, I. J.: Relationships of trace gases and aerosols and the emission characteristics at Lin'an, a rural site in eastern China, during spring 2001, J. Geophys. Res., 107(D12), 4157, doi:10.1029/2001JD000724, 2002.

Wang, Z. W., Zhang, X. S., Chen, Z. S., and Zhang, Y.: Mercury concentrations in size-fractionated airborne particles at urbanand suburban sites in Beijing, China, Atmos. Environ., 40, 2194 2201, 2006.

Wang, Z. W., Chen, Z. S., Duan, N., and Zhang, X. S.: Gaseous elemental mercury concentration in atmosphere at urban and remote sites in china, J. Environ. Sci.-China, 19, 176-180, 2007.

Xiu, G., Cai, J., Zhang, W., Zhang, D., Bueler, A., Lee, S., Shen, Y., Xu, L., Huang, X., and Zhang, P.: Speciated mercury in sizefractionated particles in Shanghai ambient air, Atmos. Environ, 43, 3145-3154, 2009.

Yang, Y. K., Chen, H., and Wang, D. Y.: Spatial and temporal distribution of gaseous elemental mercury in Chongqing, China, Environ. Monit. Assess., 156, 479-489, 2009.

Zhang, H., Feng, X., Larssen, T., Qiu, G., and Vogt, R. D.: In inland China, rice, rather than fish is the major pathway for methyl mercury exposure, Environ. Health Perspect., 118(9), 1183-1188, doi:10.1289/ehp.1001915, 2010.

Zhang, Q., Streets, D. G., Carmichael, G. R., He, K. B., Huo, H., Kannari, A., Klimont, Z., Park, I. S., Reddy, S., Fu, J. S., Chen, D., Duan, L., Lei, Y., Wang, L. T., and Yao, Z. L.: Asian emissions in 2006 for the NASA INTEX-B mission, Atmos. Chem. Phys., 9, 5131-5153, doi:10.5194/acp-9-5131-2009, 2009. 